\title{
ADMINISTRATIVE BARRIERS AND THEIR IMPACT ON THE EFFICIENCY OF ORGANIZATIONS IN HOUSING CONSTRUCTION: THE CASE OF ST. PETERSBURG
}

\author{
Sergey Oparin ${ }^{1}$, Marina Yudenko $^{2}$, Nadezhda Polovnikova $^{3}$, Svetlana Nikolikhina $^{4}$
}

\begin{abstract}
The purpose of the article is to draw attention to the importance of the issue related to administrative barriers in the field of housing construction, the redundancy of which leads to the rise of transaction costs and reducing the effectiveness of organizations. The estimate of the creation of formal rules in the context of social infrastructure in St. Petersburg is given. The conclusion is made about the direct impact of the effective standard on the effectiveness of the organization. An integral method for measuring the economic efficiency of the resources used is proposed, which improves the quality of the measurement and the evaluation of their effectiveness, taking into account the impact of transaction costs.
\end{abstract}

JEL Classification Numbers: D23, K23, M48, DOI: 10.12955/cbup.v7.1367

Keywords: administrative barriers, construction, the dualist principle, transaction costs, efficiency

\section{Introduction}

The relevance of the article is due to the fact that housing construction is associated with a high level of administrative barriers that affect the efficiency of construction organizations through the growth of transaction costs. Improving efficiency does not always require the use of new technology, advanced technology and production methods. Formal rules, mediated through laws and regulations that reduce transaction costs, can increase aggregate performance and efficiency without introducing innovations. But more often than not there is a situation when excessive administrative barriers increase the transaction costs of economic entities in the field of housing construction. Certainly, housing construction is a sphere of construction that is substantially subject to state regulation. However, the price of excessive regulation is the predominance of the restrictive function of social institutions (formal rules and regulations) over the coordinating and regulating functions in the activities of economic entities. The reasons explaining the lack of interaction between large and small businesses are numerous, such as imperfection in the legislation, which is the most important one, which is stated in the paper by Barkhatov and colleagues (2017).

The task of the presented paper is to draw the attention of interested participants of the investment and construction process to the need to create effective standards governing construction as a type of economic activity.

Study of the process of formation of rules in the housing construction of St. Petersburg literature review

Housing construction is not only the construction of a residential building, but it is also social and engineering, including transport infrastructure. That is why housing construction requires state regulation. But the philosophical principle of dualism or the principle of two irreducible principles comes into effect. On the one hand, state regulation is objectively necessary, on the other hand, excessive administrative barriers arise, hampering housing construction. The question arose, where is the "middle ground" and how to make social institutions that regulate housing construction effective? We claim that, an effective institution will be if it creates incentives to achieve an effective result without additional formal rules and regulations and without additional transaction costs.

As an example, we study the state of the formal standard "contribution to infrastructure development" in housing construction in St. Petersburg. In 2013 the construction committee brought into force to the social infrastructure contribution. Yudenko M., Yudenko E. (2017, p. 18) investigated the data of the committee on construction - the committee prepared a special account for which contributions were received by developers who built residential buildings designed to accommodate up to 100 people. It

\footnotetext{
${ }^{1}$ Faculty of Economics and Management, Emperor Alexander I St. Petersburg State Transport University, oparinsg@mail.ru

${ }^{2}$ Management Department, Saint Petersburg State University of Economics, mnuspb@mail.ru

${ }^{3}$ Faculty of Economics and Management, Emperor Alexander I St. Petersburg State Transport University, nadezhda_horosh@mail.ru

${ }^{4}$ Faculty of Economics and Management, Emperor Alexander I St. Petersburg State Transport University, ukas85@yandex.ru
} 
was explained to the developers that contributions will accelerate the process of approval of documentation on the projects implemented by them. Construction organizations were asked to contribute amounts to this account, calculated on the basis of the existing rules of security of residents with social infrastructure. Thus, the committee calculated that on average one place in school costs 1,044 thousand rubles, and a place in kindergarten costs 1,200 thousand rubles. Since 2018, housing developers in St. Petersburg have initiated the process of transfers for the development of social infrastructure in the amount of 4-5 thousand rubles from each square meter. Transfers should be made to the Fund of social obligations. Initially, the purpose of the creation of this fund was to solve the problem of the shortage of kindergartens (it was planned to build 40 kindergartens at the estimated rates). But, with the implementation of such, at first glance, an initiative agreeable to all, immediately there were administrative barriers to its effective implementation. The administration decided to increase contributions to 11 thousand rubles in order to solve through the money collected and other problems related to the social infrastructure of the city. The total amount of fees should be 30 billion rubles annually. It was assumed that the creation of the fund of social obligations should make the rules for the construction of social infrastructure facilities uniform for all. The fund should serve as a customer for the construction of social infrastructure facilities and assist in the selection of contractors.

Using the example of the implementation of the "contribution to the development of social infrastructure" standard, we observe the principle of dualism. On the one hand, the issue of transferring this institutional standard to the category of a formal rule has been resolved, which helps to really make this contribution a working mechanism and fix the earmarking of such payments. On the other hand, the initiative of developers turned out to be punishable, which can lead to opportunism of developers for its execution.

It should be duly noted that thanks to the efforts of the Russian government, experts note a decrease in the number of administrative barriers in construction, which confirms the optimality of the chosen course in terms of reforming construction regulation. Currently, all administrative procedures in construction are regulated. Any investor and construction organization has a clear understanding of the completeness, the composition of documents, duration and result of receiving the state service. In St. Petersburg in 2013, a headquarters was set up to improve the business environment in order to eliminate excessive administrative barriers for entrepreneurs. The Headquarters consists of managers and employees of the St. Petersburg authorities (53 people), as well as leading business associations and enterprises of the city (121 people).

\begin{tabular}{|c|c|c|}
\hline Figure 1: The size of the social burden of housing developers \\
\hline $\begin{array}{c}\text { Market value } \\
\text { of economy } \\
\text { class housing } \\
79 \text { thousand } \\
\text { rubles }\end{array}$ The size of the social burden of developers, per $\mathrm{m}^{2}$ \\
\hline Social burden \\
\hline Source: Authors price
\end{tabular}

Administrative barriers are reduced by the decisions of the Government of the Russian Federation - so order No. 2568-r of November 18, 2017, was signed, which approves the plan for the preparation of regulatory documents necessary for the abolition of overlapping procedures, as well as improving the implementation of procedures in the construction of non-residential facilities. In particular, 12 excessive procedures were excluded from the list of procedures in the field of construction of nonresidential capital construction objects. As a result, it was possible to optimize the procedure for connecting such facilities to systems of heating, hot and cold water supply and wastewater disposal. In 2017, the exhaustive list of procedures in the field of housing construction decreased by 40 
procedures, mainly due to the optimization of procedures for connecting CIC objects to engineering networks. Currently, the list includes 96 procedures, while in 2013 it included 256 procedures.

Natalya Antipina, Deputy Minister of Construction and Housing and Public Utilities of the Russian Federation at the plenary session of the conference Real estate market 2019: working in new conditions in her speech «Digitalization in construction will reduce administrative barriers for developers» (2018), notes that the Ministry has been working on solutions for the first time to reduce administrative barriers in the construction industry, including working on digitizing procedures in the construction industry. She notes that:

The reform was carried out on the territory of two cities - Moscow and St. Petersburg. Today, these entities have completely transferred all construction procedures to "digital". Due to this process, the time to obtain a building permit has been reduced. Today it is about 7 working days.

These measures, according to the deputy minister, will bring a positive effect on the entire construction complex.

It is no secret that there is traditionally a certain opposition between supporters of the introduction of new regulatory measures and those who, on the contrary, are in favour of weakening state regulation. In difficult times for the country's economy, the demand for those and other solutions is growing. A business (especially a small one) complains that it lacks the strength to receive various approvals and permits. Oparin, Chepachenko and Yudenko (2018) consider that the crisis pushes small businesses into the shadows, while the industry bodies believe that it is possible to resist this process at the expense of regular permitting procedures. They write about informal rules as follows:

One the current problem of the Russian economy is a high level of administrative barriers affecting the business activities of entrepreneurs. These administrative barriers are the rules about conducting certain activities in the market that have been established by decisions of state bodies for compliance, which is an indispensable condition for conducting such activities (p.340).

Officials of the Ministry of Economic Development believe that excessive rules and regulations increase the administrative burden of entrepreneurs and contribute to their withdrawal into the shadow business. The authors of the monograph Fedoseev, Yudenko and colleagues (2018) believe that in a difficult economic situation, it should be taken into account that entrepreneurs have fewer resources to comply with regulatory requirements, while society has fewer opportunities to pay for these increased demands, even if it makes demands on them. And to the question of how to find a balance between the interests of society, the state and entrepreneurs, the authors of the article consider the correct answer to be that we should not be talking about the quantitative composition of the authorization procedures, but about their quality, i.e. it should be about effective rules and regulations governing the construction industry.

Studies carried out by the Institute for Urban Economics allowed to structure regional and local administrative procedures not regulated by federal legislation. In an article Polidi (2014, p.92) gives the following data: $90.7 \%$ of administrative procedures established in violation of Federal law; 9.8\% of administrative procedures additionally installed because of the incompleteness of the Federal legislation and $17.2 \%$ of administrative procedures do not contradict the Federal legislation.

If we are talking about administrative barriers, then it is necessary to understand that we should pay attention to transaction costs that are not directly related to production. The research of the problems of transaction costs in the field of construction is devoted to the scientific works of the authors: Asaul, Ivanov (2013), Furubotn and Richter (2000) and other scientists or institutionalists.

We will focus on the aspect of the interaction between transaction costs and administrative barriers below. Auzan in his book (2016, p.42) analyzes transaction costs: "horizontal costs", "vertical costs", "diagonal costs", "diminishing costs", "incremental costs" and "optional costs". According to the authors of this article, administrative barriers clearly define the transaction costs vertically. Where the vertical is built, prohibitive-high management costs arise. In any vertical, the rights of the one who is above are limited by a number of circumstances, including the interests and possibilities of the one who is below and vice versa. If we recall the classic manifestation of opportunistic behaviour, then this is shirking. As soon as the employer enters into negotiations with employees to ensure that they should 
not shirk, but should engage in direct official duties, the vertical begins to deviate slightly. But the largest hierarchy is the state. The vertical, which creates administrative barriers and leads to an increase in transaction costs, is manifested in the brightest way. With a certain number of links in the hierarchy of officials and with their own interests among those who control them, the signal from the top can be distorted and interpreted in its own way. And as a result, there is an increase in transaction costs when ownership rights and freedoms are limited according to the command principle. Transaction costs vertically are also due to administrative barriers ensuring the legalization of corruption flows. Due to the existence of such barriers, payments are not directly related to taxes but are legal payments (various certificates, documents confirming unnecessary compliance), i.e. it is a legal business and technology for issuing certificates and confirmations.

\section{Results}

Methodical approach to determining the effectiveness of organizations in housing construction. Taking into account that the more efficient the rule regulating this or that type of activity, the less administrative barriers affect the change in transaction costs, the authors of the article proposed a method for determining the effectiveness of total resources used in production and business activities of organizations engaged in housing construction.

In the article, the enterprise's effectiveness $(E F)$ is to be calculated according to the following formula:

$$
E F=\frac{S F F}{L R+F A \times \mathrm{E} n+W o C+\Delta \mathrm{TA}},
$$

where: $E F$ - the effectiveness of the totality of the applied resources;

$S F F$ - the balanced financial result of organizations operating in housing construction;

$\triangle T A$ - transaction costs of organizations operating in housing construction;

$L R$ - the total cost of labour resources (the cost of labour of workers of organizations of the CIC, accruals for labour remuneration (in the legally established procedure), expenses of the organization for training, retraining and advanced training of employees);

$F A$ - the average cost of the active and passive parts of fixed assets (at initial or replacement cost) of organizations operating in housing construction;

$E n$ - the calculated value of the coefficient of bringing one-time costs to current (recommended to be calculated as the inverse of the weighted average of the standard useful life of fixed assets);

$W o C$ - the average value of the entire set of working capital involved in the production and sale of construction products of organizations operating in housing construction.

The numerator of the formula (SFF) is the final financial result, determined on the basis of the accounting data of all business transactions of organizations engaged in housing construction, and represents the amount of the balanced financial result (profit or loss) from the sale of goods, products (works, services), reduced by the amount of expenses. The authors' proposal consists of the need to take into account the costs of organizations (the denominator of the formula) indicator of transaction costs (A). Yudenko M.N., Yudenko E.A. (2019, p.224) there are two types of transaction costs: entrepreneurial and regulatory. Entrepreneurial arise as a response to the low level of organization of the investment and construction market, the lack of existing practice of interaction of counterparties. Regulatory arise in the process of implementation by the entities of legislative norms and rules for the execution of contracts, property rights and permits. It is the regulatory transaction costs that are the costs due to the opportunistic behavior of the construction participants and the administrative barriers of the institution of power. Unfortunately, transaction costs are not subject to accounting, which creates difficulties in accounting for them. The authors of the article believe that management accounting in construction organizations has tools for accounting for transaction costs. According to Daraban (2018, p.76), management accounting, being part of the "corporate infrastructure" of organizations, is one of the most important suppliers of data and information for the management decision-making process.

\section{Conclusion and proposals}

The search for a successful solution of a problem of the qualitative effectiveness measurement of the results of activities of construction organizations objectively necessitates following an indissoluble 
link with the methodology for measuring the effectiveness of economic systems. In this regard, the conceptual methodical approach to solving this problem is considered by the authors of the article to follow the principle of measuring the economic result (effect) to the costs (resources) that led to its receipt. A special problem is the practical implementation of following this principle when implementing a resource method for measuring economic efficiency, which can be solved in two ways:

By implementing a local method of measuring the economic efficiency of each individual resource, which necessitates the introduction of high-quality management accounting, which allows determining the proportion of the economic effect obtained from the contribution of the corresponding resource;

By applying the integral method of measuring economic efficiency, calculated on the basis of the total aggregate of resources used, as the ratio of the total economic effect to the total valuation of the resources used, resulting in this effect.

The guarantee of the successful functioning of organizations and enterprises engaged in activities in housing construction is an increase in the efficiency of their activities. Achieving the required level of efficiency is the most important practical task of top management. But not everything depends on the entrepreneurs themselves - it is sometimes difficult to achieve the necessary level of efficient activity if rules and regulations prevail that improperly restrict the activities of entrepreneurs or ineffective rules. In the works of few scientists, for example Posner (1979) or Schäfer (1998) the question of the effectiveness of the legal rule is raised. The results of their research are arguments that do not contradict the conclusion of the authors of the article that the effectiveness of legal rules is directly related to effective business activities.

\section{References}

Auzan A. (2016). Ekonomika vsego. Kak instituty opredelyayut nashu zhizn' [The Economy of everything. How institutions define our life]. M.: Mann, Ivanov and Ferber.

Asaul A .N., Ivanov S. N. (2013). Structure of Transactional Costs of Business Entities in Construction. World Applied Sciences Journal 23 (Problems of Architecture and Construction). 80-83.

Barkhatov V., Nikolaeva E. \& Belova I. (2016). Taxation and Transaction Costs as Factors of Business Success in MediumSized Enterprises in Russia. Entrepreneurship, Business and Economics. Proceedings of the 15th Eurasia Business and Economics Society Conference, 1. 129-137. DOI: https://doi.org/10.1007/978-3-319-27570-3_12.

Daraban M. C. (2018). Business value created by management accounting. Proceedings of the Conference: Innovations in Science and Education Prague, Czech Republic. DOI: http://dx.doi.org/10.12955/cbup.v6.1136.

Digitalization in construction will reduce administrative barriers for developers. 2018, from https: //m.asninfo.ru/news/82736-tsifrovizatsiya-v-stroitelstve-snizit-administrativnyye-baryery-dlya-zastroyshchikov.

Oparin S., Chepachenko N. \& Yudenko M. (2017). The role of social institutions in the activity of entrepreneurs in the construction sector. Proceedings of the Conference: Innovations in Science and Education Prague, Czech Republic. DOI: http://dx.doi.org/10.12955/cbup.v5.948.

Polidi T.D. (2014). Housing construction in Russia: investment climate and administrative barriers. Property relations in the Russian Federation. 2 (149).89-99.

Posner R. (1979). Utilitarianism, economics and legal theory. Journal of legal stugies. 8.103.

Schäfer H.B. (1998). Efficiency as a legal norm. Law and economics. Methodology and application. Copenhagen: Diøf publishing. 95-111.

Fedoseev I.V., Yudenko M.N., Chepachenko N.V., Waldemar W. Budner, Salov A.A., Nikolikhina, S.A., Polovnikova N.A. (2018). Issledovaniye rosta i razvitiya stroitel'nykh organizatsiy na rynke nedvizhimosti. [Study of the growth potential and development of construction organizations in the real estate market.] SPb.: Publishing: Saint-Petersburg State University.

Furubotn Eiric G., Richter Rudolf. (2000). Institutios and Economic Theory. The contribution of the new institutional economics. The University of Michigan Press.

Yudenko M.N., Yudenko E.A. (2017). Vliyaniye transaktsionnykh izderzhek na effektivnosti stroitel'nykh organizatsiy [The impact of transaction costs on the efficiency of construction organizations] . Vestnik of the Faculty of Saint-Petersburg State University. 2. 67-75.

Yudenko M.N., Yudenko E.A. (2019). The institution of the state and its impact on the transaction costs of entrepreneurs in construction. XIV International Scientific and Practical Conference: Modern Management: Problems and Prospects. St. Petersburg: SPbGEU. 